\title{
ANALISIS DAMPAK PENDIDIKAN POLITIK DALAM MENINGKATKAN PARTISIPASI POLITIK PEMILIH PEMULA DI SMAN 1 BALAURING LEMBATA NTT
}

\author{
Adnan Pattipeilohy, Nurbani Yusuf, Trisakti Handayani \\ FKIP Universitas Muhammadiyah Malang, Indonesia \\ Email: pattipeilohyadnan@gmail.com
}

\begin{abstract}
ABSTRAK
Usaha sadar dan terencana untuk mewujudkan suasana belajar dan proses pembelajaran agar peserta didik secara aktif pengembangkan potensi yang dimiliki seperti kekuatan spiritual keagamaan, pengendalian diri, kepribadian, kecerdasan, dan memiliki akhlak mulia. Untuk mewujudkan masyarakat yang sejahtra tidak mudah tanpa keterlibatan pendidikan politik yang efektif.Pendidikan Politik yang efektif ialah mampu memberikan pemahaman kepada masyarakat tentang Hak dan Kewajibannya dalam Bidang Politik. Hal demikian yang ditanamkan pada Pemilih Pemula khususnya Siswa Sekolah Menengah Atas (SMA) Negeri 1 Omesuri Balauring. Bukan hanya memberikan kesadaran akan Hak dan kewajibannya dalam momentum Demokratis Pemilihan Kepala Daerah Bupati dan Wakil Bupati pada 15 Februari 2017 lalu tetapi juga memberikan pemahaman untuk menjadi Pemilih Cerdas yang tidak Dekriminatif kedaerahan dan Kesukuan ataupun sentiment Agama tetapi berdasarkan kemampuan memimpin tawaran visi misi yang ditawarkan para calon Bupati dan wakil bupati Lembata periode 2017 - 2022. Adapun tujuan dalam penelitian ini ialah sebagai berikut: 1) Menjelaskan bentuk-bentuk pendidikan politik pada pemilih pemula yang dilaksanakan oleh Panitia Pemilihan kecamatan pada pemilih pemula di SMAN 1 Balauring Kabupaten Lembata. 2) Mendeskripsikan dampak pendidikan politik yang dilakukan oleh Panitia Pemilihan Kecamatan pada pemilih pemula di SMAN 1 Balauring Kabupaten Lembata. Penilitian ini menggunakan teknik penelitian deskriptif kualitatif. Dimana peneliti terjun langsung untuk menggali informasi terkait dengan judul dari penelitian. Pengumpulan data diperoleh dengan teknik wawancara, observasi, dan dokumentasi.Adapun informasi yang perlu digali informasinya adalah pemilih pemula SMAN 1 Balauring dan anggota Panitia Pemilihan Kecamatan (PPK).Berdasarkan hasil penelitian diperoleh hasil sebagai berikut: 1) Pendidikan politik yang menjadi tanggung jawab Komisi Pemilihan Umum (KPU) Kabupaten Lembata yang dilaksanakan di sekolah-sekolah salah satunya SMAN 1 Balauring, melalui Panitia Pemilihan Kecamatan (PPK) Omesuri dilakukan dengan metode sosialisasi pemilih pemula dengan sasaran Siswa-siswi SMAN 1 Balauring dengan kisaran umur 17 Tahun keatas dengan metode penyampaian ke kelas-kelas layaknya metode pengajaran biasa dan melalui alat bantu ajar yaitu bahan tayang materi tentang kepemiluan yang disampaiakan oleh KPU dan PPK. Materi yang disampaikan antara lain: Pengertian umum tentang Pemilu, Pemilih Pemula, syarata-syarat menjadi pemilih, dan PPK juga menyampaikan tentang kategori pemilih cerdas yang memilih berdasarakan kemampuan kepemimpinan, visi dan misi yang ditawarkan oleh calon Bupati dan Wakil Bupati. 2) Tujuan dari adanya pendidikan politik oleh KPU dan PPK adalah selain memberikan kesadaran akan hak yang dimiliki oleh pemilih pemulah juga untuk menekan angkah golongan putih (Golput). Melalui wawancara yang dilakukan oleh peneliti, adapun dampak dilihat dari respon Siswasiswi setelah adanya sosialisasi atau pendidikan politik oleh PPK yaitu kesadaran untuk hadir dan ikut memilih pada tanggal 15 Februari 2017.
\end{abstract}

Kata Kunci : Pendidikan, Politik, Efektif, Tujuan, Pemilih, Pemilih Pemula, Cerdas, Pemimpian, bupati, wakil bupati. 


\begin{abstract}
The enterprises are conscious and planned to realize learning atmosphere and learning process so that students are actively developing the potential possessed such as spiritual strength, self-control, personality, intelligence, and have good morale. To realize it is not easy without effective political education. It is education to given understanding to the public about rights and obligations in the political field. That things should be instilled in the novice voter especially student of SMA Negeri 1 Balauring. It is not only about provides awareness of his rights and obligations in the election of regents and vice regents on 15 February 2017,but provide an understanding to be an intelligent voter who does not decriminate regionalism or ethnic or religious sentiments but based on the leadership ability and vision of the mission offered by candidates for the period 2017-2022.The purpose of this research is: 1). To explains the forms of political education in novice voters that conducted by the district election committee on the novice voters in SMA Negeri 1 Balauring Kabupaten Lembata. 2). To describe the impact of political education undertaken by the district election committee on the novice voters in SMA Negeri 1 Balauring Kabupaten Lembata. this research used qualitative descriptive research technique. For this case researchers go directly to search for information related to the title of the research. The technique to collected data is interview, observation and documentation. Any information that needs to be searched is the novice voter in SMA Negeri 1 Balauring and a member of Panitia Pemilihan Kecamatan (PPK).Based on the research results obtained the following results: 1). the political education which is the responsibility of the Komisi Pemilihan Umum (KPU) is implemented in the schools of one of the SMA Negeri 1 Balauring, through Panitia Pemilihan Kecamatan (PPK) Omesuri is done with the method of socialization of novice voters with the target students of SMA Negeri 1 Balauring with the age range of 17 years and over with the method of delivering to the classroom as usual teaching methods and through teaching aids that material about the election submitted by KPU and PPK. The material presented is general understanding of elections, novice voters, voter conditions, and PKK also presented about the intelligent voter category that chooses based on leadership ability, vision and mission offered by candidates. 2) the purpose of political education by KPU and PKK is reduce the number of voters who do not vote (Golput). Through interviews conducted by the researchers obtained the results of the impact of student responses after the socialization or political education by PPK is the awareness to attend and vote on 15 February 2017.
\end{abstract}

Keyword:Education, Political, Effective, Purpose, Votes, Novice voters, Intelligent, leader, Regents, Vice Regents

\section{PENDAHULUAN}

Salah satu hal penting dalam agenda reformasi 1998 adalah terlindunginya dan terjaminnya atas hakhak dasar manusia yang bukan saja bernilai semantic, yang dimaksud dengan nilai semantic di sini adalah bukan saja terlindungi dan dijamin secara tertulis dalam Konstitusi Negara akan tetapi dalam penerapannya pula mampu terjamin dan terlindungi. Hak konstitusional merupakan hak-hak Warga Negara yang dijamin dan diatur dalam konstitusi menjadi pilar penting pelaksanaan Negara Hukum. Di mana setiap apa yang menjadi tindakan Negara haruslah berdasarkan aturan yang tertulis, dalam hal ini peraturan perundang-undangan mulai dari UUD Negara RI Tahun 1945 sampai pada Peraturan Daerah tingkat Desa.

Hak-hak dasar itu salah satunya adalah hak memperoleh kesempatan yang sama dalam pemerintahan, sebagaimana diatur dalam UUD Negara RI Tahun 1945 Pasal 28D Ayat (1) dan Ayat (3), yaitu: "setiap warga negara berhak memperoleh kesempatan yang sama dalam pemerintahan”. Pasal tersebut memberikan

Adnan Pattipeilohy, dkk. Analisis Dampak Pendidikan Politik dalam Meningkatkan Partisipasi Politik Pemilih Pemula di SMAN 1 Balauring Lembata NTT 
pengertian bahwa setiap Warga Negara mempunyai hak yang sama dalam pemerintahan, hak yang sama dimaksud adalah bagaimana tidak adanya pembedaan oleh Negara terhadap orang-orang untuk terlibat dalam pemerintahan, yang salah satunya adalah hak memilih dan dipilih. Pembatasan hak hanya dapat dilakukan oleh Negara yang itupun ditetapkan oleh Undang-Undang, hal ini sebagai bentuk penghormatan dan pengakuan atas hak dan kebebasan orang lain dalam tujuan pembentukan Negara yang demokratis.

Pemenuhan hak konstitusional sebagaimana disebutkan di atas adalah bagian dari upaya pemerintah dalam mencapai tujuan Negara sebagaimana diisyaratkandalam Pembukaan UndangUndang Dasar Negara RI Tahun 1945 alinea ke-IV, yang antara lain melindungi segenap bangsa Indonesia dan seluruh tumpah darah Indonesia dan untuk memajukan kesejahteraan umum, mencerdaskan kehidupan bangsa, dan ikut melaksanakan ketertiban dunia yang berdasarkan kemerdekaan, perdamaian abadi dan keadilan sosial. Mencapai tujuan Negara yang tertera dalam aline ke-IV tersebut diselenggarakan berdasarkan Ketuhanan yang Maha Esa, Kemanusiaan yang Adil dan Beradab, Persatuan Indonesia, Kerakyatan yang Dipimpin oleh Hikmat Kebijaksanaan dalam Permusyawaratan Perwakilan, Keadilan Sosial Bagi Seluruh Rakyat Indonesia.

Bentuk nyata dari dasar dan tujuan Negara yang dipaparkan di Paragraf sebelumnya adalah melalui pelaksanaan kedaulatan Rakyat Indonesia yaitu Pemilihan Umum, baik Pemilihan Umum ditingkat Pemilihan Presiden dan dan Legislatif, juga melalui Pelaksanaan kedaulatan ditingkat Daerah yaitu Provinsi memilih kepala daerah ditingkatnya yaitu
Gubernur hingga pelaksanaan kedaulatan ditingkat Kabupaten/Kota untuk memilih kepala daerah Bupati dan Wakil Bupati atau wali kota dan wakil wali kota. Melalui Undang-Uundang pelaksanaan Kedaulatan Rakyat atau Undang-Undang Pemilu inilah bisa jadi terdapat pembatasan-pembatasan hak-hak sebagaimana diamanatkan oleh UUD Negara RI Tahun 1945.

Pemilihan Umum atau yang disingkat pemilu dalam ketentuan umum UndangUndang Nomor 15 Tahun 2011 Tentang Penyelenggaraan Pemilihan Umum memberikan pengertian, Pemilu adalah sarana pelaksanaan Kedaulatan Rakyat yang diselenggarakan secara langsung, umum, bebas, rahasia, jujur, dan adil dalam Negara Kesatuan Republik Indonesia berdasarkan pancasila dan Undang Undang Dasar Negara Republik Indonesia Tahun 1945.

Berbicara tentang Pemilu, terdapat beberapa persoalan penting yang berkaitan dengan Hak konstitusional Warga Negara dalam pelaksanaan Pemilu tersebut.Salah satunya adalah hak untuk berpartisipasi dalam pesta demokrasi baik ditingkat lokal daerah sampai tingkat Nasional.Bentuk partisipasi tersebut adalah berhak dan bebas menentukan pilihan politiknya tanpa ada tekanan dari manapun, sampai pada persoalan ditingkat terpenuhi atau tidaknya seseorang dikategorikan sebagai pemilih, dalam hal ini persoalan pada daftar pemilih tetap.Tentang pendidikan politik oleh partai politik sampai pada tingkat partisipasi masyarakat atau warga Negara dalam pelaksanaan pesta demokrasi. Persoalan mulai dari tidak terwadahinya warga Negara yang memenuhi persyaratan sebagai pemilih dalam DPT (Daftar Pemilih Tetap), dipangkasnya hak politik oleh karena persoalan Prosedural formal, hingga dimasukkannya mereka yang tidak lagi 
memenuhi syarat sebagai pemilih dalam DPT.

Warga Negara harus memenuhi syarat sebagai pemilih, agar dapat masuk atau terdaftar dalam pemilih tetap atau DPT. Dalam Undang-Undang Nomor 1 Tahun 2015 tentang Penetapan Peraturan Pemerintah Pengganti Undang-Undang Nomor 1 Tahun 2014 tentang Pemilihan Gubernur, Bupati, dan Walikota menjadi Undang-Undang dalam ketentuan umum pasal 1 poin ke-6 memberikan pengertian pemilih adalah penduduk yang berusia paling rendah 17 (tujuh belas) tahun atau sudah/pernah kawin yang terdaftar dalam pemilihan umum.

Berusia paling rendah 17 (tujuh belas) tahun merupakan syarat pertama sebagai pemilih. Usia tujuh belas tahun merupakan usia yang dikategorikan dalam pendidikan maka ditingkat Sekolah Menengah Atas berkisar pada Kelas XI dan XII oleh karena hal tersebut maka Komisi Pemilihan Umum dalam Tahapan Pemilu memberikan Ruang kepada Penyelenggara untuk mensosialisasikan Pelaksanaan Pemilu pada pemilih pemula di tingkat Sekolah Menengah Atas sebagai bentuk pendidikan politik dan meningkatkan partisipasi politik Warga Negara dan menekan terjadinya golongan putih akibat ketidaktahuan pemilih.

Pemilihan Umum yang dilakukan serentak pada tanggal 15 Februari 2017 yang berlangsung di beberapa daerah di tingkat Provinsi dan kabupaten/kota di seluruh Indonesia salah satunya dilangsungkan di Kabupaten Lembata, Provinsi Nusa Tenggara Timur. Kabupaten Lembata yang memekarkan diri dari Kabupaten Flores Timur pada Tahun 1999 artinya bahwa usia Otonomi Daerah yang masih seumur jagung menjadikan Proses Pemilukada kali ini sebagai langkah penting dalam membangun Daerahnya.
Kabupaten Lembata yang jumlah Pemilih Tetapnya sekitar 72.339 pemilih yang terdiri atau tersebar dari 9 (Sembilan) kecamatan yaitu Kecamatan Omesuri, Buyasuri, Lebatukan, Ileape, Ileape Timur, Nubatukan, Wulandoni, Atadei dan Nagawutun. Untuk kecamatan Omesuri yang jumlah DPT 9802 pemilih memiliki sasaran pemilih pemula yaitu SMA Negeri 1 Balauring yang berada di ibukota kecamatan Omesuri.

SMA Negeri 1 Omesuri yang berdiri Tahun 2013, sebagai sekolah baru ditingkat Menengah Atas, SMA N 1 Balauring menjadi magnet baru bagi Lulusan Menengah Pertama dan Madrasah Tsanawiyah di Kecamatan Omesuri. Sehingga beberapa siswa yang berstatus sebagai siswa putus sekolah dan yang tidak melanjutkan ke jenjang Menengah Atas karena faktor geografis jarak SMA lain yang jauh kemudian melanjutkan untuk bersekolah di SMA Negeri 1 Balauring. Sehingga usia ideal sesuai jenjang tidak teratur, Kelas X, XI, dan kelas XII tidak mesti berumur sesuai jenjang yang sewajarnya akan tetapi kelas XI pun terkadang beberapa siswa telah berumur 18 hingga 20 Tahun. Hal ini kemudian menjadi penting mengingat bahwa usia yang demikian telah mampu memenuhi syarat sebagai pemilih dan menjadi objek dalam sosialisasi Pemilih Pemula. Namun bagaimana sosialisasi dan pendidikan politik oleh Partai Politik mampu berdampak dan memberikan kesadaran kritis kepada siswa bahwa usia demikian telah memenuhi syarat sebagai usia yang memiliki Hak Konstitusional yang dijamin oleh konstitusi dan menjadi penentu arah Kabupatennya kelak. Sebagai bentuk langkah aplikasinya adalah hadir di Tempat Pemungutan Suara (TPS) dan menentukan pilihan politiknya sebagai bentuk nyata Partisipasi Politiknya.

Adnan Pattipeilohy, dkk. Analisis Dampak Pendidikan Politik dalam Meningkatkan Partisipasi Politik Pemilih Pemula di SMAN 1 Balauring Lembata NTT 
Berdasarkan uraian latar belakang di atas, maka penulis tertarik untuk melakukan penelitian lebih lanjut atas fenomena partisipasi politik pemula di Balauring Lembata Nusa Tenggara Timur terutama di SMAN 1 Balauring. Dengan judul “Analisis Dampak Pendidikan Politik Dalam Meningkatkan Partisipasi Politik Pemilih Pemula di SMAN 1 Balauring Lembata NTT".

\section{METODE}

Jenis penelitian yang digunakan dalam penelitian adalah pendekatan deskriptif kualitatif. Artinya, data yang dikumpulkan bukan berupa angka-angka, melainkan data tersebut berasal dari datadata, wawancara, catatan lapangan, dokumen pribadi, dan dokumen resmi lainnya.Sehingga yang menjadi tujuan dari penelitian kualitatif ini adalah menggambarkan realita empirik di balik fenomena secara mendalam, rinci dan tuntas. Oleh karena itu, penggunaan pendekatan kualitatif dalam penelitian ini adalah dengan mencocokkan antara datadata yang telah ada dengan kenyataan yang ada di lapangan.

Metode Penelitian kualitatif sebagai prosedur penelitian yang menghasilkan data deskriptif berupa kata-kata tertulis, lisan dan orang-orang yang dapat diamati melalui metode penelitian deskriptif.Penelitian ini bermaksud untuk membuat diskripsi atau gambaran secara tertulis mengenai kenyataan yang sesungguhnya ada dengan teknik pengumpulan datanya, tidak diubah dengan bentuk simbol atau bilangan.

Menurut Zuriah (2009:92), penelitian kualitatif bersifat generating theory bukan hypothesis testing sehingga teori yang dihasilkan berupa teori substantif. Penelitian kualitatif memerlukan ketajaman analisis, objektivitas, sistematis, dan sistemik sehingga di peroleh ketepatan dalam interprestasi, sebab hakikat dari sesuatu fenomena atau gejala bagi penganut penelitian kualitatif adalah totalitas atau Gestalt.

Jenis penelitian dalam penelitian ini adalah menggunakan pendekatan kualitatif. Penelitian yang lebih bersifat deskriptif sehingga metode kualitatif lebih mudah apabila berhadapan dengan kenyataan ganda.Jenis dan pendekatan kualitatif ini bertujuan untuk mencari data-data tentang Analisis dampak pendidikan politik dalam meningkatkan partisipasi politik pemilih pemula di SMAN 1 Balauring Lembata Nusa Tengga Timur.

\section{HASIL DAN PEMBAHASAN}

Bentuk-bentuk Pendidikan Politik pada Pemilih Pemula yang dilaksanakan oleh Panitia Pemilihan Kecamatan pada Pemilih Pemula di SMA Negeri 1 Balauring Kabupaten Lembata

Pendidikan politik dapat diartikan sebagai usaha yang sadar untuk mengubah proses sosialisasi politik masyaarakat sehingga mereka memahami dan menghayati betul nilai-nilai yang terkandung dalam suatu sistem poltik yang ideal yang hendak dibangun. Alfian, 1986:235 (dalam Sumantri, 2003:23).Pada pendidikan politik, peneliti meneliti Pemilih pemula terdiri dari siswa SMAN 1 Balauring yang berada dikabupaten lembata yang telah memenuhi syarat untuk memilih, dengan mengkaji kembali pemahaman terhadap pendidikan politik pemilu pemula oleh penyelenggara pemilihan umum oleh siswa SMAN 1 Balauring.

a) Bahan bacaan

Salah satu faktor yang mempengaruhi partisipasi politik pada pemilih pemula dalam pelaksanaan pilkada Kabupaten Lembata 2017 adalah Media social atau 
media massa, dalam hal ini media social Facebook. Media social dalam hal ini berperan besar dalam mensosialisasikan tentang Pilkada Kabupaten Lembata 2017, serta memberikan penilaian tentang kredibilitas masing-masing kandidat. Selain itu media social mempengaruhi pendidikan politik pemilih pemula karena media sosial turut menginformasikan profil para kandidat serta Visi dan Misi mereka.

Media social maupun media massa memang turut berpengaruh terhadap pendidikan politik maupun partisipasi politik seseorang. Milbrath yang dikutip oleh Michael Rush dan Althof (1989:168) mengungkapkan bahwa keterbukaan dan kepekaan seseorang terhadap perangsang politik diantaranya melalui media masa akan memberikan pengaruh bagi keikutsertaan seseorang dalam kegiatan politik.

Era politik modern saat ini, peran media sosial memang sangat signifikan. Dalam konteks politik modern, media sosial tidak hanya menjadi bagian yang integral dari politik, tetapi juga memiliki posisi sentral dalam politik. Hal ini disebabkan sifat media sosial atau media massa yang dapat menyangkut pesan-pesan (informasi dan citra) secara massif dan menjangkau banyak kalangan atau publik terpancar luas (Leviane Jackelin Hera Lotulung, 2012: 40-41). Media sosial atau media masa memang berperan untuk memberikan pengetahuan kepada masyarakat tentang karakter masing-masing kandidiat. Pengetahuan individu sebagaimana dijelaskan oleh Nasiwan (2010: 33) berpengaruh terhadap perilaku politiknya.

Partisipasi pemilih pemulah di SMAN 1 Balauring dalam dalam pemberian suara di pemilu kepala daerah kabupaten lembata tanggal 5 februari 2017 cukup baik. Pemilih pemula di SMAN 1 Balauring merka antusias dalam kegiatan tersebut kerena hal ini merupakan pengalaman pertama mereka sehingga mereka merasa penasaran. Sayangnya tidak ada data pasti tentang angka pemilih pemula karena pencoblosan bersifat rahasia.Partisipasi yang cukup baik dari para pemilih pemula di SMAN 1 Balauring mencerminkan telah tercapainya tujuan pendidikan politik dalam meningkatkan partisipasi politik pemilih pemula. Terkait dengan hal ini, Mohammada Najib (2005:136) mengemukakan salah satu tujuan program pendidikan dan informasi pemilu adalah rakyat mampu memberikan suaranya pada pemilu secara tepat sesuai dengan pilihannya sendiri

b) Siaran Radio dan Televisi serta film (audio visual media)

Pengertian "Radio" menurut ensiklopedi Indonesia yaitu penyampaian informasi dengan pemanfaatan gelombang elektromagnetik bebas yang memiliki frequensi kurang dari $300 \mathrm{GHz}$ (panjang gelombang lebih besar dari $1 \mathrm{~mm}$ ). Sedangkan istilah "radio siaran" atau "siaran radio" berasal dari kata "radio broadcast" (Inggris) atau "radio omroep" (Belanda) artinya yaitu penyampaian informasi kepada khalayak berupa suara yang berjalan satu arah dengan memanfaatkan gelombang radio sebagai media. Televisi adalah: media telekomunikasi terkenal yang berfungsih sebagai penerima siyaran gambar bergerak beserta suara, baik itu monokrom (hitam putih) maupun berwarna.

Selain bahan bacaan bentuk pendididkan politik sangat dipengaruhi oleh siaran radio, dan televisi yang memiliki pengaruh yang signifikan terhadap pendidikan politik pemula dalam berpartisipasi pilkada, hal ini karena siaran radio dan televisi merupakan sumber informasi secara langsung didengar dan 
dilihat oleh pemilih pemula maupun masyarakat umum terhadap para calon pemimpin daerah, yang dapat memaparkan visi misi selama lima tahun kedepan, sehingga menjadi tolak ukur pemilih pemula dalam memilih seorang pemimpin daerah. Pendidikan politik merupakan suatu proses dialogik diantara pemberi dan penerima pesan sehingga diharapkan informasi yang diberikan melalui media radio dan televisi kepada para anggota masyarakat memperoleh sikap dalam orientasi terhadap kehidupan berpolitik yang berlangsung dalam masyarakat.Pada prinsipnya pendidikan politik bertujuan untuk menggubah dan membentuk tata perilaku seseorang agar sesuai dengan tujuan politik yang dapat menjadikan setiap individu sebagai partisipasi politik yang bertanggung jawab.

Pendidikan politik bagi para pemula yang dilakukan melalui siaran radio maupun televisi sangat penting karena masih banyak pemilih tetap (spektator) maupun pemilih pemula yang belum memiliki pilihan maupun sikap politik, yang disatu sisi mengguntungkan, disatu sisi merugikan.Pendidikan politik yang diberikan melalui siaran radio dan televisi diharapkan mampu membawa para pemilih pemula untuk menjadi simpatik terhadap para calon. Namun apabila pendidikan politik tidak dilakukan dengan baik dengan sendirinya akan dijauhi oleh para pemilih pemula dan bahkan pemilih tetap akan semakin apatis terhadap kegiatan politik. Hal ini sesuai dengan pendapat Rusadi kantaprawira (2004:55) yang menyatakan bahwa pendidikaan politik merupakan upaya untuk meningkatkan pengetahuan rakyat agar mereka dapat berpartisipasi secara maksimal dalam sistim politiknya, salah satu bentuk pendidikan politik yang dapat dilakukan adalah melalui siaran radio dan televisi.
Berdasarkan hasil pengamatan peneliti selama penelitian di lokasi penelitian di tempat beradanya SMAN 1 Balauring kecamatan Omesuri kabupaten Lembata bahwa: dikabupaten lembata khususnya kecamatan Omesuri desa Balauring tidak adanya pendidikan politik yang secara langsung disampaikan melalui siaran radio dan siaran televisi lokal yang menyampaikan pendidikan politik kepada pemilih pemula maupun pemilih yang spektator. Hal ini karena siaran radio lokal Fm yang berada di kabupaten lembata tidak menjaungkau sampai di kecamatan omesuri, khususnya desa Balauring serta minat masyarakat terhadap siaran radio di desa Balauring sangat rendah, dan tidak adanya siaran televisi lokal yang berada di Kabupaten Lembata. Hal ini lah yang menjadi satu hambatan dalam memberikan pendidikan berpolitik terhadap masyarakat setempat.

c) Lembaga atau asosiasi dalam masyarakat

Pemahaman tentang pendidikan berpolitik pemilih pemula di SMA 1 Balauring mengenai pemilihan kepala dearah Bupati dan wakil Bupati tanggal 15 februari 2017. Merupakan usaha sadar untuk mengubah proses sosialisasi masyarakat khususnya siswa SMAN 1 Balauring sehingga mereka memahami dan mengahayati betul nilai-nilai politik yang terkandung dalam sistim politik yang ideal yang hendak dibangun. Hasil pemahaman itu diharapkan melahirkan sikap dan tingkah laku politik baru yang mendukung sistim politik yang ideal itu sendiri, dan bersamaan dengan itu lahir pula kebudayaan politik baru di daerah setempat, dikhususkan lagi bagi siswa SMAN 1 Balauring.

Dampak Pendidikan Politik yang dilakukan oleh Panitia Pemilihan Kecamatan pada Pemilih Pemula di SMA 


\section{N 1 Balauring Kabupaten Lembata}

Pada pertanyaan peneliti dengan tujuan mengetahui dampak pendidikan politik dan sosialisasi pemilih pemula terhadap tingkat partisipasi politik siswa SMAN 1 Balauring pada pemilihan umum kepala daerah dikabupaten lembata tahun 2017, menunjukkan bahwa hasil sosialisasi pendidikan politik, pemilih pemula mampu menciptakan penyelenggaran pilkada berjalan secara demokratis dan penuh dengan rasa tanggung jawab. Para pemilih pemula selalu ikut serta secara aktif dalam pesta demokrasi. Lebih lanjut hasil sosialisasi yang dilakukan panitia pemilihan kecamatan (PPK) pemilih pemula tidak golput, dapat diketahui secara kuantitatif dan secara kualitatif dari hasil pilkada'pada pemilihan kepala daerah di kabupaten Lembata. Hal ini dapat dibuktikan berdasarkan hasil wawancara dengan responden menunjukan bahwa semua responden yang diwawancarai oleh peneliti itu menggunakan hak pilihnya dalam pemilu yang dilakukan di kabupaten Lembata khususnya di SMAN 1 Balauring berlangsung, umum, bebas, rahasia, jujur, bersih proporsional, akuntabilitas, efektivitas, efisien serta anti politik uang. Hal ini sesuai dengan asas pemilihan umum dan asas penyelengara pemilihan umum yang terdapat dalam undang-undang no 15 tahun 2011 tentang penyelenggara pemilihan umum, keberhasilan memberikan sosialisai terhadap proses pendidikan politik pemula, sangat tergantung pada metode yang diberikan.

Partispasi politik pada pemilih pemula dalam pelaksanaan pilkada Kabupaten Lembata 2017 juga dipengaruhi oleh kelompok pergaulan. Biasanya pemilih pemula masih memiliki figur-figur yang dianggap disegani,karena dianggap lebih pintar sehingga memiliki pengetahuan yang cukup untuk memberikan penilaian terhadap para calon bupati dan wakil bupati. Selain itu, biasanya pemilih pemula yang masih usia pelajar memiliki rasa seperjuangan akan teman itu tinggi. Apabila dalam diskusi kelompok mengenai salah satu kandidat itu baik maka semua menggap kandidat tersebut baik. Pemilih pemula masih labil dan bingung menentukan pilihan yang terbaik, karena mereka belum tahu benar akan politik. Teman pergaulan memang merupakan salah satu faktor yang menentukan partisipasi politik pada pemilih pemula dalam pelaksanaan pilkada Kabupaten Lembata 2017. Hal ini sejalan dengan pandangan Amond (Mochtar Mas'oed, 2011: 46-49) yang mengemukakan bahwa kelompok pergaulan merupakan salah satu sarana sosialisasi politik. Di dalam kelompok pergaulan setiap anggota memperoleh kedudukan yang relative sama dan memiliki ikatan-ikatan yang erat. Kelompok pergaulan tersebut mensosialisasikan anggotanya dengan cara mendorong atau mendesak mereka untuk menyesuiakan diri terhadap sikap atau tingkah laku yang dianut oleh kelompoknya. Kelompok pergaulan memang tidak selamanya berpengaruh terhadap partisipasi pemilih pemula dalam Pilkada 2017.Hal ini tergantung pada masing-masing karakter dan pendirian mereka.Para pemilih pemula mungkin sering membicarakan mengenai kandidat Pilkada Lembata mengenai plus minus mereka.Akan tetapi, pemilih pemula yang berpendirian kuat cenderung mempunyai pilihan tersendiri dan tidak ikut teman-teman. Kekuatan pengaruh sosialisasi politik sebagaimana diungkapkan oleh Allen Beck (dalam Cholisin, 2007) bagi setiap orang memang tidak sama karena hal ini juga tergantung pada intensitas individu terhadap sarana maupun derajat individu yang mendalami

Adnan Pattipeilohy, dkk. Analisis Dampak Pendidikan Politik dalam Meningkatkan Partisipasi Politik Pemilih Pemula di SMAN 1 Balauring Lembata NTT 
proses sosialisasi politik serta umur individu. Dengan demikian, dapat disimpulkan bahwa pengaruh kelompok pergaulan terhadap partisipasi individu dalam pilbup tergantung pada intensitas individu dalam menjalin interaksi terhadap teman sepergaulan, serta posisi individu dalam kelompok pergaulan. Makin sering individu berinteraksi dengan kelompoknya, tentunya dia akan mudah terpengaruh dengan partisipasi politik teman-temannya, apalagi jika di kelompoknya dia tidak mempunya penguruh yang besar. Seiring pertambahan usia, dimana individu makin dewasa dan berpengalaman, pengaruh teman pergaulan terhadap orientasi politik individu makin berkurang.

Hal diatas dapat di analisis bahwa pengambaran yang sering muncul tentang tentang pemilih pemula adalah kurangnya pengalaman dan pengetahuan dalam bidang politik menjadikan mereka tidak percaya diri dalam menentukan pilihannya, ketika dihadapkan dengan moderenisasi saat ini seharusnya pemilih pemulah harus aktif dalam bidang politik, karena bidang politik merupakan bagian dari menjalankan peran mereka dalam masayrakat.

Dengan melihat kondisis/keadaan lapangan seperti ini, perlu adanya peningkatan kualitas teori dalam menyampaikan pendidkan politik pemilih pemula, karena pemilih pemula yang memiliki peran besar dalam menumbuh kembangkan suatu bangsa, lebih dikhususkan perkembangan dikabupaten Lembata.

\section{SIMPULAN}

Pendidikan Politik yang menjadi Tanggung jawab Komisi Pemilihan Umum (KPU) Kabupaten Lembata yang dilaksanakan di Sekolah - sekolah salah satunya Sekolah Menengah Atas (SMA) Negeri 1 Balauring, Omesuri melalui Panitia Pemilihan Kecamatan (PPK) kecamatan Omesuri dilakukan dengan Metode Sosialisasi Pemilih Pemula dengan sasaran Siswa - siswi SMAN 1 Balauring dengan kisaran umur 17 Tahun keatas dilakukan dengan metode Penyampaian ke kelas - kelas layaknya metode Pengajaran biasa dan melalui Alat bantu Ajar yaitu Bahan Tayang materi Tentang Kepemiluan yang disiapkan Oleh KPU dan PPK. Adapun materi - materi yang disampaikan Antara Lain : Pengertian Umum Tentang Pemilu, Pemilih Pemula, Syarat- syarat menjadi Pemilih dan di daftarkan sebagai Pemilih dalam Daftar Pemilih Tetap (DPT) oleh KPU. Selain itu PPK juga menyampaikan Tentang Pemilih yang dikategorikan sebagai Pemilih Cerdas dan Berkualitas dengan Kriteria Memilih berdasarkan Kemampuan Kepemimpinan Calon Bupati dan Wakil Bupati, visi dan Misi yang ditawarkan Dalam Program kerjanya, dan Track Record Calon. Bukan memilih berdasarkan Sentimen Kedaerahan, Agama, Suku Ras tertentu. Memilih yang Deskriminatif. Metode klasik ini dianggap Afektif karena bertatapan langsung dengan Siswa dan Mampu diterima dan diaplikasikan dalam bentuk hadir di Kantor desa melihat Daftar Pemilih Tetap dan ikut berpartisipasi pada saat 15 Februari 2017 di TPS Tempat Pemungutan Suara untuk ikut memilih.

Tujuan Dari adanya Pedidikan Politik oleh KPU dan PPK adalah selain memberikan kesadaran akan Hak yang dimiliki Oleh Pemilih Pemula juga untuk menekan Angka Golongan Putih (Golput) yaitu Pemilih yang memilih untuk tidak Hadir di TPS pada saat tanggal Pemilihan. Melalui wawancara yang dilakukan oleh Peneliti, adapun dampak 
dilihat dari Respon siswa - siswi setelah adanya sosialisasi atau pendidikan Politik Oleh KPU yaitu kesadaran untuk hadir dan ikut memilih pada tangal 15 Februari 2017. Hal ini dapat diketahui oleh peneliti melalui penelitian lanjutan. Adapun metode mengetahui tingkat dampak pendidikan politik oleh PPK dan KPU adalah melalui wawancara tentang pengetahuan dan informasi apa saja yang di dapat oleh Siswa - siswi setelah proses pendidkan dan Sosialisasi politik. Yaitu antara Lain : berdasarkan hasil wawancara dengan responden menunjukan bahwa semua semua responden yang diwawancarai oleh peneliti itu menggunakan hak pilihnya dalam pemilu yang dilakukan di kabupaten Lembata khususnya di SMAN 1 Balauring berlangsung, umum, bebas, rahasia, jujur, bersih proporsional, akuntabilitas, efektivitas, efisien serta anti politik uang. Hal ini sesuai dengan asas pemilihan umum dan asas penyelengara pemilihan umum yang terdapat dalam undang-undang no 15 tahun 2011 tentang penyelenggara pemilihan umum, keberhasilan memberikan sosialisai terhadap proses pendidikan politik pemula, sangat tergantung pada metode yang diberikan.

Bahwa tingkat keefektifan siswa dalam menerima materi yang disampaikan pun dipengaruhi oleh metode penyampaian. Perlu adanya perubahan metode ataupenembahan metode. Selain melalui penyampaian di kelas melalui bahan tayang dan materi lain. KPU seharusnya karena mempertimbangkan Sebagai Pemilih Pemula pengalaman untuk ikut memilih di TPS adalah baru di alami pada Pemilihan tersebut. Agar tidak Kaku maka ada Seperti metode Simulasi Proses Pemilihan yang di lakukan di Sekolah - sekolah. Mulai dari Prosesi Pengecekan nama di Daftar Pemilih Tetap sampai pada Tahapan memilih dalam Bilik suara. Sehingga metode simulasi ini menjadi Latihan awal sebelum Hari $\mathrm{H}$ pemilihan. Hal ini membantu siswa agar tidak lagi malu, ataupun takut untuk hadir di TPS sehingga mampu menekan tingkat Golput.

1. Perlu ada tindak lanjut oleh Lembaga Kepemiluan KPU dan PPK atas prosesi Sosialisasi di sekolah melalui Sosialisasi lanjutan untuk mengetahui Tercapai tidaknya Target menekan angka Golput pada Pemilu dan memberikan kesadaran kepada Pemilih Pemula. Dan Jika Perlu, pada pemilu selanjutnya perlu adanya "TPS Sekolah" Khusus Pemilih Pemula maupun “TPS Berjalan” kepada Pemilih Pemula di Sekolah - sekolah.

\section{DAFTAR PUSTAKA}

Alfian. 1986. Perkembangan Ilmu Politik.Ramdja kary. Bandung

Cholisin, 2002.Materi pokok ilmu kewarganegaraan-pendidikan kewarganegaraan.UNY. Yogyakarta

Kantraprawira, Rusadi, 1988. System Politik Indonesia: suatu model pengantar. Sinar baru. Bandung

Mas'oed Muctar dan Win mac Andrew, 2008.Perbandingan sistim politik. Gajah mada university press. Yogyakarta

Sumantri, Endang. 2003. Pendidikan Politik. Universitas Terbuka. Jakarta

Zuriah, nurul 2009.Metodologi penelitaan social dan pendidikan. Bumi aksara. Jakarta

UUD Negara RI Tahun 1945

UU Nomor 1 Tahun 2015 pengganti UU Nomor 1 Tahun 2014

Adnan Pattipeilohy, dkk. Analisis Dampak Pendidikan Politik dalam Meningkatkan Partisipasi Politik Pemilih Pemula di SMAN 1 Balauring Lembata NTT 